\title{
FORMATION OF THE PERSONALITY OF A FUTURE DOCTOR THROUGH EXTRACURRICULAR ACTIVITIES AT THE DEPARTMENT OF MICROBIOLOGY, VIROLOGY AND IMMUNOLOGY: EXPERIENCE AND PERSPECTIVES
}

\section{Т. В. Дерев'янко, І. М. Звягольська \\ Українська медична стоматологічна академія, Полтава \\ ФОРМУВАННЯ ОСОБИСТОСТІ МАЙБУТНЬОГО ЛІКАРЯ В КОНТЕКСТІ ПОЗААУДИТОРНОЇ РОБОТИ НА КАФЕДРІ МІКРОБІОЛОГЇ̈, ВІРУСОЛОГІЇ ТА ІМУНОЛОГІЇ: ДОСВІД І ПЕРСПЕКТИВИ}

\begin{abstract}
The article describes the experience of organizing and conducting extracurricular educational work at the Department of Microbiology, Virology and Immunology of Ukrainian Medical Stomatological Academy, aimed at shaping the personality of future doctors. Particular attention is paid to the fact that extracurricular work is focused on the development of independence, creativity, competitiveness and other fundamental personality traits of a specialist with higher education. An effective means of promoting students' creative self-fulfillment is a system of individual, group and collective forms of activity. Organization of extracurricular work with students at the Department of Microbiology, Virology and Immunology is based on the principles of humanization; cooperation; voluntariness; expediency; interest; binary practical orientation. The implementation of these principles is carried out through generally accepted directions: national and patriotic, intellectual and spiritual, civil and legal, moral, ecological, aesthetic, labor and physical education, promotion of a healthy lifestyle. The department staff uses the following forms for organization of national upbringing: information digests, communication hours, round tables, reading conferences, competitions, debates, discussions, ethical conversations, excursions, and brain-rings, focused on the topics of various nature.
\end{abstract}

Key words: extracurricular work; education; personality; students; Department of Microbiology, Virology and Immunology.

Анотація. У статті висвітлено досвід організації та проведення форм позааудиторної виховної роботи на кафедрі мікробіології, вірусології та імунології Української медичної стоматологічної академії, які спрямовані на формування особистості майбутніх лікарів. Акцентовано увагу на тому, що позааудиторна робота спрямована на розвиток самостійності, креативності, конкурентоздатності та інших основоположних рис особистості спеціаліста з вищою освітою. Ефективними засобами, що сприяють творчій самореалізації студентів, є система індивідуальних, групових і колективних форм діяльності. Організація позааудиторної роботи зі студентською молоддю на кафедрі мікробіології, вірусології та імунології базується на таких принципах, як: гуманізація, співробітництво, добровільність, доцільність, інтерес, бінарна практична спрямованість, реалізація яких здійснюється за загальноприйнятими напрямами: національно-патріотичного, інтелектуально-духовного, громадянськоправового, морального, екологічного, естетичного, трудового та фізичного виховання, утвердження здорового способу життя. Для організації національного виховання колектив кафедри використовує такі форми: інформ-дайджести, години спілкування, круглі столи, читацькі конференції, конкурси, диспути, дискусії, етичні бесіди, екскурсії, брейн-ринги, тематика яких має різноманітний характер.

Ключові слова: позааудиторна робота; виховання; особистість; студентська молодь; кафедра мікробіології, вірусології та імунології.

Introduction. At present, higher education prioritizes training of highly qualified specialists, who, along with the formation of professional competences in their chosen specialty, develop harmoniously, acquire the ability to successfully fulfill their duties in the team, appreciate the value of creative evolution and are ready 
to perform their public and constitutional obligation. Therefore, educational work should be aimed at formation of moral values; development of the student's independent thinking, their individual creative abilities; formation of spirituality and emotional component of the personality, in particular development and education of such traits as compassion, kindness, justice, conscience, perception of beauty, tolerance, sense of personal dignity and dignity of another person, etc.

The main goal of national education of students, including future doctors, is to prepare a developed, socially active personality, a professionally literate, creative specialist, combining high spirituality, moral purity, professional competence and physical excellence [5]. In the modern context of competition in the labor market, there is a tendency of increased requirements for professional training of the individual, which requires the implementation of innovative approaches to the system of professional culture formation. After all, one of the main tasks in the new national model of higher education is to develop the creative personality of a future competitive specialist with high culture, qualities of a citizen and patriot, an intellectual and socially active personality.

The current stage in the development of the Ukrainian society places high demands on the quality of doctors training. An important role in shaping the professional qualities and spirituality of healthcare professionals belongs to the harmonious development and upbringing of the individual. Indeed, the doctor should contribute to the promotion of spirituality and moral qualities, as well as the universal values in all spheres of the society. In this regard, special attention is given today to the issues of improving the efficiency of the professional training of future doctors in higher education. The implementation of the inner potential of the student's personality and the professional culture formation depend to a large extent on the successful organization of extracurricular work with students as a process of their self-development. Extracurricular work is aimed at the development of independence, creativity, competitiveness and other fundamental personality traits of a specialist with higher education [4].

The aim - to highlight the experience of organizing and conducting forms of extracurricular educational work at the Department of Microbiology, Virology and Immunology of Ukrainian Medical Stomatological Academy (hereinafter - UMSA), focused on shaping the personality of a future doctor.

Theoretical framework. In our opinion, the academic subject "Microbiology, Virology and
Immunology” has a significant training, educational and outlook-developing potential at higher medical institutions of education. This subject not only forms the theoretical and practical basis for their professional training, but also plays a significant socio-cultural role $[1,3]$. The implementation of educational and training goals in the context of studying microbiology, virology and immunology is one of the most important elements of the modern cognitive process, since the educational environment, both at practical sessions, during lectures and extracurricular activities, allows students to reveal their potential, form an active life position, the ability to gain experience of correct behavior and communication, stable moral qualities of the individual.

The Department of Microbiology, Virology and Immunology of UMSA has created all the conditions for manifestation of a free, creative and moral personality of a student who must possess intelligence, which cannot be achieved without preserving and reviving the spiritual and historical values of their country, priority development of culture, science and education as the necessary sources of progress for the society with a guaranteed future. The educational environment of the department actively engages Ukrainian and foreign students of the 2nd year of study (Dental Faculty), the 2nd and 3rd years of study (Medical Faculty), as well as students with a normative term of study in the specialties 221 "Dentistry", 222 "Medicine" and 228 "Pediatrics".

The department carries out its educational activities in accordance with the normative documents that regulate this area of work at a higher education institution [5]: Constitution of Ukraine, Law of Ukraine "On Education”, Law of Ukraine "On Higher Education", National Doctrine for the Development of Education of Ukraine in the 21st Century, Concept of National Education of Students Youth, Regional Target Program of National and Patriotic Education of Children and Youth for 2017-2020, "Strategy of National and Patriotic Education of Children and Youth for 2016-2020", order of the Ministry of Healthcare of Ukraine No. 687 as of November 27, 2008 "On Improving Educational Work in Higher Medical and Pharmaceutical Educational Institutions of the I-IV levels of Accreditation, Institutions of Postgraduate Education, Research Institutions and Institutions of Health Care", Statute of Ukrainian Medical Stomatological Academy, Paradigm of Upbringing Modern Students of the Academy (curator's advisor), plans of educational work of UMSA and the Department 
of Microbiology, Virology and Immunology for the current academic year.

Organization of extracurricular work with students at the Department of Microbiology, Virology and Immunology is based on the principles of humanization; cooperation; voluntariness; expediency; interest and binary practical orientation [4]. Effective tools that promote students' creative self-fulfillment are the system of individual (assignments, creative tasks, individual conversations, etc.), group (excursions, creative groups, holidays, competitions, olympiads, etc.) and collective (round tables, role-playing games, trainings, moderation, "discussions swings", etc.) forms of activity that involve the maximum number of participants and provide mastering a variety of behavior patterns by students.

Extracurricular work of the department is aimed at developing professional and social values of the student's personality. The first category includes involvement of students in participation in scientific circles, students' scientific society, research projects, olympiads, conferences. Such activities are professional in nature; they unite students with common preferences and require considerable effort, consistency, commitment and motivation. Students are actively involved in the work of the students' scientific society, which is actively promoted at the Department of Microbiology, Virology and Immunology. It is a multifaceted process that is motivated and coordinated by experienced educators and involves the acquisition of skills for independent work with scientific literature, mastering the research methods, development of the ability to analyze and interpret the obtained results, to present their achievements at the annual students' scientific and practical conference. This form of activity is aimed at forming a creative and hardworking personality, ready for life and work under the conditions of market relations, fostering discipline, self-discipline, organization, development of one's own observations, cognitive interests in microbiology, invention and intellectual development of students. In the system of tasks, facing educators, an important place belongs to the formation of students' responsible attitude, which involves the development of socially significant motives, including the desire to learn conscientiously and properly, interest in knowledge, need for knowledge, which is directly dependent on those internal conditions in which the student's activity takes place.

Extracurricular work of the second (group) category is of more general and educational nature, and can bring together students of different specialties. This includes, in particular, engaging students in sports sections, drama and dance groups, excursions, visits to exhibitions and museums in order to cover the main directions of the department's educational work.

In the direction of the formation of human values, humanization and humanitarization are of particular importance in the process of reviving the spirituality of the people. The concept of humanism is closely related to the human sciences, and therefore requires the knowledge from the complex of natural and social sciences. Based on this approach for education of the doctor's personality, the staff of the department pays considerable attention to the creation of sociocultural environment, which stimulates and ensures the development of moral consciousness, stable moral qualities, moral needs of the individual, formation of an active life position, education of humanistic attitude to the patient, emphasizing the role not only of the acquired knowledge, but also the sensorial perception of the patient. Empathy, just as professionalism, is only manifested when the doctor possesses a baggage of universal and moral and spiritual values. These include, in particular, humanity, kindness, honesty, diligence, responsiveness, compassion, discipline, conscientiousness, benevolence, national dignity, justice, the sense of collectivism, intelligence, the sense of patriotism, ecological and legal culture.

The following forms are used for organization of moral education by the department staff: information digests, communication hours, round tables, reading conferences, debates, discussions, ethical conversations, the topics of which are of various nature ("Human Rights", "Freedom in Human Life and Beyond", "Corruption and Favoritism Steal our Future", "Legal Consciousness as an Indicator of Successful Education", etc.). At the beginning of the academic year, in each academic group, the curators organize and conduct the first informational class on the topic “Acquiring Academic Integrity by Students". In order to prevent the spread of xenophobic and racist manifestations among students, information hours on the topic "We are Different but We are Equal" are necessarily organized. Students are actively engaged in the All-Ukrainian actions: "Youth against Crime and Violence", "Give Joy to Children", "Youth against Drugs and AIDS", "Donate Blood - Save a Life", "Assistance to Soldiers of Joint Forces Operation" and others.

One of the priority areas of educational work at the Department of Microbiology, Virology and Immunology 
is national-patriotic and civic education of students, aimed at the development of the citizen as a high-moral personality, cherishing Ukrainian traditions, spiritual values, possessing relevant knowledge, skills and abilities, capable of implementing one's potential under conditions of modern society, professing European values, and ready to fulfill the obligation to protect the independence and territorial integrity of Ukraine. Students are actively engaged in academic, citywide and regional national, military-patriotic events, actions, projects, educational information hours, which are aimed at forming the axiological orientations and public commitment, raising the level of knowledge about prominent personalities of Ukrainian state formation, political leaders, current issues of Ukrainian history, popularization of national and spiritual heritage of Ukraine ("Poltava City Day", "Defender of Ukraine Day", "Day of Liberation of Ukraine from Fascist Invaders”, "Day of Memory of Kruty Heroes”, "Day of the Heavenly Hundreds Heroes", "Chornobyl Disaster Remembrance Day”, "Day of Dignity and Freedom”, "Constitution Day" and others). One of the forms of extracurricular work in the direction of national and patriotic education of students is organization and conducting of excursions to the museums of Poltava: Museum of the Armed Forces of Ukraine, located on the basis of the 179th Training Center of Armed Forces of Ukraine, National Military History Museum of Ukraine, Museum of Heavy Bomber Aviation, History Museum of Poltava Battle, Museum of Aviation and Cosmonautics. An active form of national and patriotic education is ensured due to round tables in curators' academic groups in order to study the distinguished names of famous people, whose lives are connected with Ukraine in the socio-economic, political, cultural and scientific spheres, including well-known scientists, doctors who worked at the Department of Microbiology, Virology and Immunology and made a significant contribution to its development and formation. Thus, when studying the history of the native land through the prism of outstanding world figures, students feel a sense of pride for their compatriots and countrymen.

In order to cultivate artistic and aesthetic tastes, the students, together with the curators, visit various exhibitions of educational and fictional literature, photo illustrations, paintings by prominent artists, students' wallpapers and posters, which are organized and held on the basis of UMSA ("World Libraries", "Anniversary Books", "Historical Places of Poltava", "Work in the Name of Ukraine", "New Horizons in the World of Books", "World through a Camera Lens", etc.).
Students have the opportunity to "taste" the book novelties at the library cafe of UMSA. For the purpose of forming local lore culture with students, cultural hikes are organized and conducted to the Mykola Yaroshenko Art Museum, M. Hohol Theater, walking and tourist excursions around Poltava and the region. Such forms of extracurricular educational work are aimed at forming the foundations of aesthetic culture and knowledge, harmonious perception and emotional attitude to the beautiful, mastering values and knowledge in the field of world and folk art, nurturing students' artistic taste, the desire to bring the wonderful to life and enhance it.

An integral component of the educational process of the department is environmental education - a system of educational activities that are designed to form an axiological attitude to nature and the formation of ecological culture on its basis [1, 3]. Today, a qualitatively new system of national environmental education should provide training for the younger generation, able to face the environmental crisis by overcoming consumer attitudes towards nature. After all, ecological training of personnel in the field of medicine is also of great national importance, since it is intended to help in solving vital socio-economic, ecological, economic and geopolitical problems. Therefore, the staff of the Department of Microbiology, Virology and Immunology pays great attention to the formation of high level of environmental consciousness and culture in future doctors, the ability to apply knowledge in the performance of their professional duties, which is an important condition for quality professional training. To this end, teachers actively organize extracurricular excursion work. Traditionally, curators of academic groups conduct excursions on the topic "Secret Destinations of Poltava”, during which students can get acquainted with the significant natural objects of the national and local importance: Poltava City Park, the Botanical Garden of V. H. Korolenko Poltava Pedagogical University [2] and other territories. Students are involved in the greening of the classrooms of the department, the All-Ukrainian action "Hand over Plastic Covers - Help the ATO Warriors", "Let’s Make Ukraine Clean Together", round table discussions are held on the topics: "Quality Water - the Future of Humanity”, "Bitterness of Chornobyl”. A compulsory element of students' environmental education is attending exhibitions "Environmental Education is the Basis of the Third Millennium", dedicated to "World Environment Day", "World Earth Day”, "This Bitter Word - Chornobyl”, "Flowers in My Flower Garden" 
and others. In our opinion, these forms of educational work are aimed at forming the intellectual, moral, aesthetic and emotional components in the ecological culture of the individual.

For the purpose of physical education and formation of a healthy lifestyle, various forms of extracurricular work are conducted, whose aim is to build up the physical abilities of the individual, development of the need for mastering sanitary and hygienic knowledge and skills, promotion of a healthy lifestyle. Students are actively engaged in the work of sports sections at the Academy, they participate in activities, devoted to the World Health Day, citywide actions to promote healthy lifestyles and prevention of diseases: "Life under Pressure" (World Hypertension Day), "I Approach the Future without Tobacco", "Drop by Drop for Life" (World Blood Donor Day), "Say "No" to Drugs", "The Pink Ribbon” (World Breast Cancer Day). In addition, in each group, information and educational discussions are regularly held. They are devoted to prevention of deviant behavior, anti-alcohol, anti-nicotine and anti-narcotics propaganda. Students are encouraged to discuss such relevant issues as prevention of HIV/ AIDS, hepatitis, tuberculosis and other especially dangerous infections.

\section{List of literature}

1. Дерев’янко Т. В. Оцінка рівня сформованості екологічної культури у студентів медичного факультету під час їх навчання на кафедрі мікробіології, вірусології та імунології / Т. В. Дерев’янко, І. М. Звягольська // Вісник проблем біології і медицини. - 2019. - Вип. 1, т. 1 (148). - С. 211-216.

2. Дерев’янко Т. В. Роль «Парку агробіостанції Полтавського педуніверситету» в еколого-естетичному вихованні студентської молоді / Т. В. Дерев'янко // Витоки педагогічної майстерності. - 2017. - Вип. 19. С. $115-121$.

3. Дерев’янко Т. В. Формування екологічних знань студентів-медиків під час вивчення мікробіології, вірусо-
Conclusions and Prospects for Research. Thus, the implementation of the basic principles and tasks of national education at the Department of Microbiology, Virology and Immunology is carried out according to the conventional scientific and pedagogical ideas and has the following vector orientation: national and patriotic, intellectual and spiritual, civil, legal, moral, ethical, physical education and promotion of a healthy lifestyle. In our opinion, one of the effective aspects in improving the future doctor's professional training is the active use of extracurricular work (mass, group, individual forms of activity). The main facilitator of the educational work in academic group is the curator, who directs the educational process, organizes and conducts extracurricular educational, cultural and training work. These forms of extracurricular educational work, which are introduced by the staff of the Department of Microbiology, Virology and Immunology of UMSA, are constantly modified, supplemented by new techniques, methods, content and tools, which give impetus to the creation of innovative approaches in a comprehensive way. In our opinion, the prospects for further research are in the study and evaluation of the spiritual, moral, emotional and aesthetic values of the student's personality.

логії та імунології / Т. В. Дерев’янко, І. М. Звягольська, В. П. Полянська // Актуальні проблеми сучасної вищої медичної освіти в Україні : матеріали навч.-наук. конф. 3 міжнар. участю (21 березня 2019 р.). - Полтава, 2019. - C. 63-65.

4. Децюк Т. М. Форми та методи позааудиторної роботи студентів у вищих навчальних закладах / Т. М. Децюк, А. А. Дударенко // Педагогічні науки. 2018. - № 3 (55). - С. 80-83.

5. Парадигма виховання сучасної студентської молоді академії (порадник куратора) / В. М. Ждан, В. М. Дворник, В. І. Похилько [та ін.] // Збірник інформаційних матеріалів з виховної роботи. - Полтава, 2019. - 48 с.

\section{References}

1. Derevianko, T.V., \& Zviaholska, I.M. (2019). Otsinka rivnia sformovanosti ekolohichnoi kultury u studentiv medychnoho fakultetu pid chas yikh navchannia na kafedri mikrobiolohii, virusolohii ta imunolohii [Evaluation of the environmental culture leven in medical students during their training in the department of Microbiology, Virology and Immunology]. Visnyk problem biolohii i medytsyny - Bulletin of Problems of Biology and Medicine, 1, 1(148), 211-216 [in Ukrainian].

2. Derevianko, T.V. (2017). Rol "Parku ahrobiostantsii Poltavskoho peduniversytetu” v ekoloho-estetychnomu

vykhovanni studentskoi molodi [The role of "Park of agrobiostation of Poltava Pedagogical University" in ecological and aesthetic education of student youth]. Vytoky pedahohichnoi maisternosti - The Sources of Pedagogical Skills, 19, 115-121 [in Ukrainian].

3. Derevianko, T.V., Zviaholska, I.M., \& Polianska, V.P. (2019). Formuvannia ekolohichnykh znan studentiv-medykiv pid chas vyvchennia mikrobiolohii, virusolohii ta imunolohii [Formation of ecological knowledge of medical students during the study of microbiology, virology and immunology]. 
Aktualni problemy suchasnoi vyshchoi medychnoi osvity v Ukraini: materialy navchalno-naukovoi konferentsii z mizhnarodnoiu uchastiu (21 berez. 2019 r.) - Topical Issues of Modern Higher Medical Education in Ukraine: Proceedings of a Study Conference with International Participation (March 21, 2019). Poltava (pp. 63-65) [in Ukrainian].

4. Detsiuk, T.M., \& Dudarenko, A.A. (2018). Formy ta metody pozaaudytornoi roboty studentiv u vyshchykh navchalnykh zakladakh [Forms and methods of extracurricular work of students in higher educational institutions]. Pedahohichni nauky - Pedagogical Sciences,3 (55), 80-83 [in Ukrainian].

5.Zhdan, V.M., Dvornyk, V.M., Pokhylko, V.I., Stavytska, N.P., \& Yushchenko, Yu.P. (2019). Paradyhma vykhovannia suchasnoi studentskoi molodi akademii (poradnyk kuratora) [Paradigm of upbringing of modern student youth of the academy (advisor to the curator)]. Zbirnyk informatsiinykh materialiv z vykhovnoi roboty - Collection of Information Materials on Upbringing Work. Poltava [in Ukrainian].

Received 05.02.20

Recommended 10.02.20 